mgr Aleksandra BALAS

Urząd Statystyczny w Katowicach

e-mail: a.balas@stat.gov.pl

\title{
Anna MOLENDA
}

Urząd Statystyczny w Katowicach

e-mail: a.molenda@stat.gov.pl

\section{KONCEPCJA DOBORU WSKAŹNIKÓW ZRÓWNOWAŻONEGO ROZWOJU POLSKI ORAZ NARZĘDZIE ICH UDOSTĘPNIANIA I PREZENTACJI}

\begin{abstract}
Streszczenie
W artykule przedstawiono założenia przyjęte w pracach nad zestawem wskaźników zrównoważonego rozwoju, kryteria doboru wskaźników, koncepcję ich grupowania według ładów i dziedzin oraz informacje w zakresie Bazy Wskaźników Zrównoważonego Rozwoju jako narzędzia służącego do udostępniania i prezentacji mierników. Materiał zawiera zaktualizowany zestaw wskaźników zrównoważonego rozwoju Polski. W artykule zaprezentowano także zarys przyszłych prac dotyczących monitorowania zrównoważonego rozwoju kraju.
\end{abstract}

Słowa kluczowe: zrównoważony rozwój, wskaźniki zrównoważonego rozwoju, wskaźniki monitorujące

\section{INDICATORS OF POLAND'S SUSTAINABLE DEVELOPMENT IN AND TOOLS FOR THEIR DISSEMINATION AND PRESENTATION}

\section{Summary}

The paper presents the assumptions used in work on a set of sustainable development indicators, criteria for the selection of indicators, and the adopted concept of their grouping by domains and areas, as well as information concerning Sustainable Development Indicators Database as a tool for sharing and presentation of indicators. The material includes an updated set of sustainable development indicators for Poland. The author also offers an outline of future work on monitoring the sustainable development of the country.

Key words: sustainable development, sustainable development indicators, monitoring indicators

JEL: Q01, O20 


\section{Wstęp}

Zrównoważony rozwój zakładający zaspokojenie potrzeb obecnego pokolenia bez umniejszania szans przyszłych pokoleń stanowi najważniejszy aspekt polityki rozwoju. Z uwagi na brak w Polsce Narodowej Strategii Zrównoważonego Rozwoju, koordynującej polityki związane ze zrównoważonym rozwojem, proces monitorowania może być realizowany z wykorzystaniem zestawu wskaźników wybranych na podstawie założeń i celów odnoszących się do wyzwań zrównoważonego rozwoju zapisanych w krajowych dokumentach strategicznych. Powyższe założenia przyjęto $\mathrm{w}$ pracach mających na celu opracowanie zestawu wskaźników do monitorowania zrównoważonego rozwoju kraju w ramach projektu pt.: Wsparcie w zakeresie rozuijania zestawu wskaźników do monitorowania narodowych strategii zrównoważonego rožwoju - Rozwój i wdrożenie polskiego zestawn wskaźników z̧równoważonego rozwoju. Projekt był realizowany w latach 2009-2011, a jego wynikiem była opracowana lista wskaźników zrównoważonego rozwoju kraju w układzie czterech ładów: społecznego, gospodarczego, środowiskowego i instytucjonalno-politycznego. W dalszych pracach za podstawę aktualizacji zestawu wskaźników przyjęto założenia i rozwiązania ustalone w trakcie realizacji wyżej wymienionego projektu, dotyczące zarówno metody doboru wskaźników, jak i ich grupowania według ładów i dziedzin. Na pierwszym etapie prace aktualizacyjne obejmowały listę wskaźników wypracowaną w ramach projektu i dotyczyły w równej mierze rewizji metryk wskaźników (dodano wyjaśnienia metodyczne, uaktualniono monitorowane cele w zakresie obowiazujących dokumentów strategicznych), jak i aktualizacji danych. Po analizie celów odnoszących się do zrównoważonego rozwoju i zapisanych w obowiązujących dokumentach strategicznych oraz po przeglądzie międzynarodowych dokumentów i baz danych związanych ze zrównoważonym rozwojem na drugim etapie opracowano propozycje nowych wskaźników do listy krajowej. Na końcowym etapie ograniczono liczbę wskaźników, biorąc pod uwagę ocenę ich znaczenia dla zrównoważonego rozwoju kraju. Wypracowany w ten sposób zestaw wskaźników stanowi propozycję statystyki publicznej w zakresie pomiaru zrównoważonego rozwoju kraju.

\section{Założenia przyjęte w pracach nad zestawem wskaźników zrównoważonego rozwoju}

W pracach nad przygotowaniem zaktualizowanego zestawu wskaźników wykorzystano formę konkretyzacji koncepcji zrównoważonego rozwoju zastosowaną w projekcie pt.: Wsparcie w zakresie rozwijania zestawn wskaźnikón do monitorowania narodonych strategii zrównoważonego rozwoju - Rozwój i wdrożenie polskiego zestawu wskaźników zrównoważonego roz̧woju. Wybór wskaźników został poprzedzony dyskusją i próbą odpowiedzi na pytanie: co chcemy mierzyć, czyli jakie elementy koncepcji zrównoważonego rozwoju będa przedmiotem pomiaru. Fundament monitoringu stanowił komplementarny opis wcześniej wymienionej koncepcji rozwoju poprzez identyfikację:

- zasad zrównoważonego rozwoju, stanowiących podstawowy „filtr” dla selekcji wskaźników; 
- $\quad$ celów jako pozytywnych stanów docelowych rozwoju, opisanych w różnych dokumentach strategicznych;

- $\quad$ ladów: społecznego, gospodarczego, środowiskowego, instytucjonalno-politycznego.

Należy podkreślić, iż zasady zrównoważonego rozwoju stanowią podstawę sprawdzenia zgodności deklarowanej koncepcji zawartej w celach i priorytetach dokumentów strategicznych z jej istotą. Kluczową jest tu zasada sprawiedliwości międzypokoleniowej przedstawiona w raporcie pt.: Our Common Future. Szczególne znaczenie dla prawidłowego działania założonego kryterium selekcji wskaźników mają zbiory zasad określone w Deklaracji z. Rio de Janeiro (tzw. Karcie Ziemi) - 27 zasad, które zostały potwierdzone w dokumencie końcowym Konferencji Narodów Zjednoczonych w sprawie Zrównoważonego Rozwoju RIO+20 Przysz̨łość jakiej chcemy, jak również przez Unię Europejską (7 głównych zasad), w polskiej polityce ekologicznej państwa (12 zasad) oraz Deklaracii Johannesburskiej.

Cele oraz łady maja charakter wzorców do osiagnięcia, do których zmierzaja zrównoważone zmiany rozwojowe. Wzajemne powiązania tych kategorii, fundamentalnych dla prawidłowego pomiaru zrównoważonego rozwoju, ilustruje rysunek 1.

\section{RYSUNEK 1.}

\section{Schemat budowy i grupowania krajowych wskaźników zrównoważonego rozwoju}

ZRÓWNOWAŻONY ROZWÓJ (ZR)

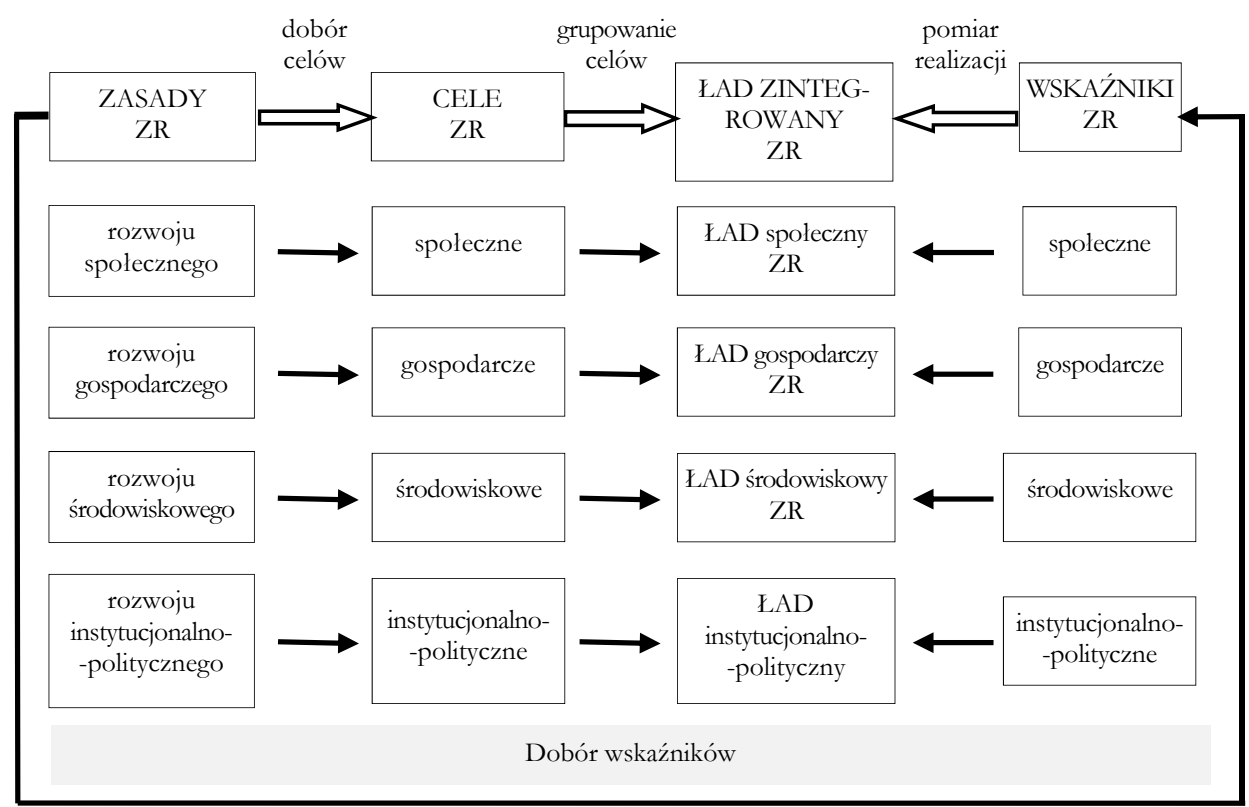

Źródło: [Wską́niki Zrównoważonego Rozpoju Polski, 2011, s.16]. 
Kategoria ładu zintegrowanego zaprezentowana na rysunku 1. to kluczowe pojęcie związane ze zrównoważonym rozwojem. Ład zintegrowany jest układem docelowym zrównoważonego rozwoju i w największym skrócie oznacza spójne (niesprzeczne), jednoczesne tworzenie ładów: społecznego, gospodarczego, środowiskowego oraz instytucjonalno-politycznego na podstawie co najmniej umiarkowanego antropocentrycznego systemu wartości. Strukturalną podstawę kształtowania ładu zintegrowanego tworzy system celów strategicznych o charakterze: społecznym, gospodarczym, środowiskowym $\mathrm{i}$ instytucjonalno-politycznym. Osiaganie tych celów jako pozytywnych stanów docelowych w określonej perspektywie czasowej rejestrują wskaźniki zrównoważonego rozwoju. Dokonując wyboru wskaźników zrównoważonego rozwoju, należy w miarę możliwości integrować łady dzięki wskaźnikom odnoszącym się do więcej niż jednego ładu.

\section{Kryteria doboru wskaźników oraz przyjęta koncepcja ich grupowania według ładów i dziedzin}

W Polsce koncepcja zrównoważonego rozwoju została uznana za zasadę konstytucyjną i jest zawarta w art. 5 Konstytucji Rzeçзypospolitej Polskiej jako jedna z zasad ustrojowych. Zrównoważony rozwój jest podstawowym celem polityki rozwoju prowadzonej na szczeblu: krajowym, regionalnym i lokalnym na podstawie odpowiednich dokumentów strategicznych. Identyfikacja celów i priorytetów odnoszących się do wyzwań zrównoważonego rozwoju zapisanych w krajowych dokumentach strategicznych stanowiła podstawę do opracowania krajowej listy wskaźników zrównoważonego rozwoju. W związku z powyższym, dokonano przeglądu i analizy założeń przyjętych w polskich dokumentach strategicznych pod kątem problematyki zrównoważonego rozwoju. Identyfikacja celów i priorytetów związanych ze zrównoważonym rozwojem oraz dobór wskaźników były prowadzone w ramach wyodrębnionych we wcześniejszych pracach czterech ładów i dwudziestu czterech dziedzin (wcześniej obszarów tematycznych).

Założono, iż zaktualizowany zestaw wskaźników powinien obejmować również aspekty, które nie zostały zapisane w krajowych dokumentach strategicznych, a które sa istotne z punktu widzenia koncepcji zrównoważonego rozwoju. Wobec tego zapoznawano się z publikacjami i artykułami polskich naukowców dotyczącymi zrównoważonego rozwoju, dokonano przeglądu wskaźników monitorujących zrównoważony rozwój w wybranych krajach członkowskich Unii Europejskiej, organizacji międzynarodowych (Europejska Agencja Środowiska, Bank Światowy, Organizacja Współpracy Gospodarczej i Rozwoju, Organizacja Narodów Zjednoczonych). Jednocześnie dokonano przeglądu celów zawartych w dokumencie końcowym szczytu RIO+20 Prayszz̨ość jakiej chcemy, w szczególności dotyczących równości płci i warunków życia, w tym ubóstwa. 
TABELA 1.

Zestawienie dokumentów strategicznych, na podstawie których dokonano wyboru celów związanych ze zrównoważonym rozwojem kraju

\begin{tabular}{|l|}
\hline Długookresowa Strategia Rozwoju Kraju - Polska 2030. Trzecia fala nowoczesności (DSRK) \\
\hline Strategia Rozwoju Kraju (SRK) \\
\hline Strategia Innowacyjności i Efektywności Gospodarki „Dynamiczna Polska 2020” (SIEG) \\
\hline Strategia Rozwoju Kapitału Ludzkiego (SRKL) \\
\hline Strategia Rozwoju Transportu do 2020 roku (SRT) \\
\hline Strategia Bezpieczeństwo Energetyczne i Środowisko (BEiŚ) \\
\hline Strategia Sprawne Państwo 2020 (SSP) \\
\hline Strategia Rozwoju Kapitału Społecznego 2020 (SRKS) \\
\hline Krajowa Strategia Rozwoju Regionalnego 2010-2020: Regiony, Miasta, Obszary Wiejskie (KSRR) \\
\hline Strategia Rozwoju Systemu Bezpieczeństwa Narodowego RP 2022 (SRSBN RP) \\
\hline Strategia Zrównoważonego Rozwoju Wsi, Rolnictwa i Rybactwa na lata 2012-2020 (SZRWRiR) \\
\hline Koncepcja Przestrzennego Zagospodarowania Kraju 2030 (KPZK) \\
\hline Umowa Partnerstwa (UP) \\
\hline Polityka energetyczna Polski do 2030 roku \\
\hline Polityka klimatyczna Polski - strategie redukcji emisji gazów cieplarnianych w Polsce do roku \\
2020 \\
\hline Polityka Leśna Państwa \\
\hline Polityka Transportowa Państwa na lata 2006-2025 \\
\hline II Polityka Ekologiczna Państwa (dokument z perspektywą do 2025) \\
\hline
\end{tabular}

Źródło: opracowanie własne.

Podczas doboru wskaźników w ramach poszczególnych ładów i dziedzin kierowano się następującymi kryteriami:

- obecność na liście wskaźników do monitorowania realizacji Strategii Zrównoważonego Rozwoju Unii Europejskiej,

- porównywalność międzynarodowa,

- dostępność danych,

- wiarygodność źródła danych.

Natomiast wśród licznych wymogów poprawności wskaźnika zrównoważonego rozwoju należy wymienić przede wszystkim:

- $\quad$ konieczność występowania związku merytorycznego z opisywanym zjawiskiem zrównoważonego rozwoju dzięki odpowiedzi na pytania: czy wskaźnik wyraża istotę zrównoważonego rozwoju oraz jaki ład, temat, jaką zasadę i jaki cel rozwojowy wskaźnik opisuje?

- poprawność formalną ocenianą na podstawie ogólnych zasad poprawności budowy wskaźnika (ocenie podlegały następujące kryteria: interpretacja-dostępność 
wyjaśnień i komentarzy ułatwiających zrozumienie treści prezentowanych informacji, teoretycźna trafność - czy wskaźnik możliwie najlepiej odzwierciedla zachodzące zjawiska, metodologia - czy istnieje jasna i czytelna metodologia obliczania wskaźnika, jakość oraz porównywalność $i$ dostępność danych).

TABELA 2.

Liczba wskaźników zrównoważonego rozwoju kraju według ładów i dziedzin

\begin{tabular}{|c|c|c|c|c|}
\hline \multicolumn{2}{|l|}{2011} & \multicolumn{3}{|l|}{2015} \\
\hline Obszary tematyczne & $\begin{array}{l}\text { Liczba } \\
\text { wskaź- } \\
\text { ników }\end{array}$ & Dziedziny & $\begin{array}{l}\text { Liczba } \\
\text { wskaź- } \\
\text { ników }\end{array}$ & $\begin{array}{l}\text { W tym } \\
\text { nowe }\end{array}$ \\
\hline \multicolumn{5}{|c|}{ LAD SPOLECZNY } \\
\hline Zmiany demograficzne & 4 & Zmiany demograficzne & 4 & 2 \\
\hline Zdrowie publiczne & 5 & Zdrowie publiczne & 5 & 2 \\
\hline Integracja społeczna & 4 & Ubóstwo i warunki życia & 6 & 2 \\
\hline Edukacja & 3 & Edukacja & 5 & 2 \\
\hline Dostęp do rynku pracy & 5 & Dostęp do rynku pracy & 6 & 1 \\
\hline Bezpieczeństwo publiczne & 2 & Bezpieczeństwo publiczne & 2 & 1 \\
\hline Zrównoważone wzorce konsumpcji & 3 & Wzorce konsumpcji & 3 & 2 \\
\hline Razem & 26 & Razem & 31 & 12 \\
\hline \multicolumn{5}{|c|}{ ŁAD GOSPODARCZY } \\
\hline Rozwój gospodarczy & 8 & Rozwój gospodarczy & 10 & 3 \\
\hline Zatrudnienie & 3 & Zatrudnienie & 4 & 2 \\
\hline Innowacyjność & 4 & Innowacyjność & 6 & 2 \\
\hline Transport & 1 & Transport & 4 & 3 \\
\hline Zrównoważone wzorce produkcji & 3 & Wzorce produkcji & 5 & 2 \\
\hline Razem & 19 & Razem & 29 & 12 \\
\hline \multicolumn{5}{|c|}{ ŁAD ŚRODOWISKOWY } \\
\hline Zmiany klimatu & 3 & Zmiany klimatu & 3 & 0 \\
\hline Energia & 4 & Energia & 4 & 0 \\
\hline Ochrona powietrza & 4 & Ochrona powietrza & 4 & 2 \\
\hline Ekosystemy morskie & 1 & Ekosystemy morskie & 1 & 0 \\
\hline Zasoby słodkiej wody & 3 & Zasoby słodkiej wody & 4 & 2 \\
\hline Użytkowanie gruntów & 3 & Użytkowanie gruntów & 4 & 1 \\
\hline Bioróżnorodność & 2 & Bioróżnorodność & 4 & 2 \\
\hline Gospodarka odpadami & 4 & Gospodarka odpadami & 5 & 1 \\
\hline Razem & 24 & Razem & 29 & 8 \\
\hline \multicolumn{5}{|c|}{ ŁAD INSTYTUCJONALNO-POLITYCZNY } \\
\hline $\begin{array}{l}\text { Globalne partnerstwo / Finansowa- } \\
\text { nie zrównoważonego rozwoju }\end{array}$ & 1 & $\begin{array}{l}\text { Finansowanie zrównoważonego } \\
\text { rozwoju }\end{array}$ & 2 & 1 \\
\hline- & - & Globalizacja handlu & 1 & 1 \\
\hline Polityka spójności i efektywności & 2 & Polityka spójności i efektywności & 2 & 1 \\
\hline Otwartość i uczestnictwo & 3 & Społeczeństwo obywatelskie - & 5 & 3 \\
\hline Aktywność obywatelska & 1 & $\begin{array}{l}\text { otwartość i uczestnictwo oraz ak- } \\
\text { tywność obywatelska }\end{array}$ & & \\
\hline- & - & Równoprawność w zarządzaniu & 2 & 2 \\
\hline Razem & 7 & Razem & 12 & 8 \\
\hline Wskaźniki ogółem & 76 & & 101 & 40 \\
\hline
\end{tabular}

Źródło: opracowanie własne. 
Po aktualizacji krajowej listy wskaźników zrównoważonego rozwoju w ramach ładów wyodrębniono 25 dziedzin. W ładzie instytucjonalno-politycznym w stosunku do poprzedniej listy wskaźników dodano dwie nowe dziedziny: Globalizacja handlu oraz Równoprawnosí w zarzqdzaniu. Natomiast dwie dziedziny zostały połączone w jedna, tj.: Spoteczeństwo obywatelskie - otwartość i uczestnictwo oraz ak.tywność obywatelska.

Obszerny zestaw wskaźników w układzie ładów i dziedzin był przedmiotem dalszych prac, które prowadzono z zamiarem ograniczenia liczby wskaźników do najlepiej obrazujących ideę zrównoważenia.

O ostatecznym doborze wskaźników do listy krajowej decydował stopień zgodności z definicją i znaczeniem wskaźnika dla zrównoważonego rozwoju. Pod uwagę brano również zjawiska specyficzne i szczególnie istotne dla Polski.

$\mathrm{Na}$ tym etapie była prowadzona współpraca z ekspertem w dziedzinie zrównoważonego rozwoju prof. dr. hab. Tadeuszem Borysem.

\section{Zaktualizowany zestaw wskaźników zrównoważonego rozwoju Polski w kontekście obowiązujących dokumentów strategicznych}

W wyniku prowadzonych prac powstał wyjściowy zestaw wskaźników zrównoważonego rozwoju, tzw. długa lista. Wykaz ten składał się z 76 wskaźników wybranych do monitorowania zrównoważonego rozwoju kraju w 2011 roku oraz 56 nowych wskaźników. W rezultacie przeprowadzonej selekcji wskaźników do listy krajowej dobrano 101 wskaźników rekomendowanych do systemu monitoringu zrównoważonego rozwoju kraju. Zestaw wskaźników do oceny zrównoważonego rozwoju kraju zawiera wskaźniki ze źródeł statystycznych, administracyjnych oraz badań prowadzonych przez inne instytucje. Charakterystyki wskaźników dokonano według jednolitego schematu opisu metodologicznego tworzącego tzw. metrykę.

TABELA 3.

Zaktualizowana lista wskaźników zrównoważonego rozwoju Polski oraz krajowe dokumenty strategiczne, których cele i priorytety stanowiły podstawę doboru wskaźników

LAD SPOLECZNY

\begin{tabular}{|l|l|c|}
\hline Lp. & \multicolumn{1}{|c|}{ Dziedzina / nazwa wskaźnika } & $\begin{array}{c}\text { Dokumenty } \\
\text { strategiczne }\end{array}$ \\
\hline & Dziedzina: Zmiany demograficzne & DSRK, SRKL \\
\hline 1. & Współczynnik dzietności & SRK \\
2. & Wskaźnik migracji zagranicznych (w \%) & SRK \\
3. & Stopa przyrostu/ubytku rzeczywistego ludności (w \%) & KSRR \\
4. & Ludność w wieku poprodukcyjnym na 100 osób w wieku produk- \\
& cyjnym & \\
\hline & Dziedzina: Zdrowie publiczne & SRKL \\
\hline 5. & Oczekiwane trwanie życia osób w wieku 65 lat w zdrowiu (w \\
& latach) & \\
\hline
\end{tabular}




\begin{tabular}{|c|c|c|}
\hline Lp. & Dziedzina / nazwa wskaźnika & $\begin{array}{l}\text { Dokumenty } \\
\text { strategiczne }\end{array}$ \\
\hline 6. & $\begin{array}{l}\text { Standaryzowane współczynniki umieralności z powodu: chorób } \\
\text { układu krażenia, nowotworów złośliwych oraz przewlekłych cho- } \\
\text { rób dolnych dróg oddechowych i cukrzycy }\end{array}$ & SRKL \\
\hline 7. & Europejski Konsumencki Indeks Zdro & DSRK, SRKL \\
\hline 8. & $\begin{array}{l}\text { Narażenie ludności miejskiej na ponadnormatywne oddziaływanie } \\
\text { pyłu PM10 }\left(\mathrm{w} \mu \mathrm{g} / \mathrm{m}^{3}\right)\end{array}$ & BEiŚ \\
\hline \multirow[t]{2}{*}{9.} & $\begin{array}{l}\text { Narażenie ludności miejskiej na powietrze zanieczyszczone ozo- } \\
\text { nem }\left(\mathrm{w} \mu \mathrm{g} / \mathrm{m}^{3} \mathrm{dziennie}\right)\end{array}$ & $B E i S ́$ \\
\hline & \multicolumn{2}{|l|}{ Dziedzina: Ubóstwo i warunki życia } \\
\hline 10. & Zagrożenie ubóstwem trwałym (w \%) & SRKL \\
\hline 11. & Wskaźnik z & SRKL, SRK, UP \\
\hline 12. & Nierówność rozkła & NSRO \\
\hline 13. & Zadłuż & SRKL \\
\hline 14. & $\begin{array}{l}\text { Liczba mieszkań oddanych do użytkowania na } 1000 \text { ludności w wieku } \\
\text { 25-34 lata }\end{array}$ & SRKL \\
\hline \multirow[t]{2}{*}{15.} & $\begin{array}{l}\text { Przeciętny miesięczny dochód do dyspozycji na } 1 \text { osobę w gospodar- } \\
\text { stwie domowym (w zł) }\end{array}$ & KSRR \\
\hline & \multicolumn{2}{|l|}{ Dziedzina: Edukacja } \\
\hline 16. & Osoby dorosłe uczestnic' & KSRR, SRKL, SRK, UP \\
\hline 17. & $\begin{array}{l}\text { Odsetek dzieci na wsi w wieku 3-4 lata objętych wychowaniem przed- } \\
\text { szkolnym (w \%) }\end{array}$ & SRKL, SZRWR R R \\
\hline 18. & Wydatki publiczne na edukację w relacji do PKB (w \%) & SRK \\
\hline 19. & Młodzież niekontyn & SRKL, SRK, KSRR, UP \\
\hline \multirow[t]{2}{*}{20.} & $\begin{array}{l}\text { Odsetek osób w wieku 25-64 lata z wykształceniem co najwyżej } \\
\text { gimnazjalnym (w \%) }\end{array}$ & SRKL \\
\hline & \multicolumn{2}{|l|}{ Dziedzina: Dostęp do rynku pracy } \\
\hline 21. & $\begin{array}{l}\text { Odsetek osób w gospodarstwach domowych bez osób pracujących } \\
(\mathrm{w} \%)\end{array}$ & SRK, SRKL \\
\hline 22. & Stopa bezrobocia długotrwałego (w \%) & NSRO \\
\hline 23. & Stopa bez & KSRR \\
\hline 24. & Wskaźnik zatrudnienia osób niepełnosp & DSRK, SRKL, SRK \\
\hline 25. & Zróżnicowanie wynagrodzeń ze względu na płeć (w \%) & NSRO \\
\hline \multirow[t]{2}{*}{26.} & $\begin{array}{l}\text { Wskaźnik zatrudnienia kobiet z najmłodszym dzieckiem w wieku } \\
\text { do } 5 \text { lat }(\mathrm{w} \%)\end{array}$ & SRKL, DSRK \\
\hline & \multicolumn{2}{|l|}{ Dziedzina: Bezpieczeństwo publiczne } \\
\hline 27. & & $\begin{array}{l}\text { Polityke Transportowa Pań- } \\
\text { stwa na lata 2006-2025 }\end{array}$ \\
\hline \multirow[t]{2}{*}{28.} & Przes & SSP \\
\hline & \multicolumn{2}{|l|}{ Dziedzina: Wzorce konsumpcji } \\
\hline 29. & Struktura samochodów osobowych według grup wieku (w \%) & SRT \\
\hline 30. & $\begin{array}{l}\text { Zużycie energii elektrycznej w gospodarstwach domowych na } 1 \text { miesz- } \\
\text { kańca (w GJ) }\end{array}$ & $B E i S ́$ \\
\hline 31. & $\begin{array}{l}\text { Struktura przeciętnych miesięcznych wydatków na } 1 \text { osobę w gospodar- } \\
\text { stwach domowych według rodzajów (w \%) }\end{array}$ & KSRR \\
\hline
\end{tabular}

\section{LAD GOSPODARCZY}

\begin{tabular}{|c|l|c|}
\hline & Dziedzina: Rozwój gospodarczy & DSRK \\
\hline 32. & $\begin{array}{l}\text { Wzrost produktu krajowego brutto na 1 mieszkańca (rok poprzed- } \\
\text { ni=100), (w \%) }\end{array}$ & KSRR, SRK \\
\hline 33. & Stopa inwestycji (w \%) & \\
\hline
\end{tabular}




\begin{tabular}{|c|c|c|}
\hline 34. & $\begin{array}{l}\text { Zróżnicowanie regionalne PKB na } 1 \text { mieszkańca według PPP na po- } \\
\text { ziomie NTS } 3(\mathrm{w} \%)\end{array}$ & NSRO \\
\hline 35. & $\begin{array}{l}\text { Dług sektora instytucji rządowych i samorządowych w relacji do PKB } \\
(\mathrm{w} \% \text { ) }\end{array}$ & SRK \\
\hline 36. & Wodochłonność gospodarki (w dam³/tys. zł) & SRK, BEiŚ, SIEG \\
\hline 37. & $\begin{array}{l}\text { Transportochłonność PKB (transport towarowy oraz transport pa- } \\
\text { sażerski) }(2000=100)\end{array}$ & $\begin{array}{l}\text { Polityka Transportowa } \\
\text { Państwa na lata 2006- } \\
\quad-2025 \text {, SRT }\end{array}$ \\
\hline 38. & Energochłonność transportu w relacji do PKB $(2000=100)$ & $\begin{array}{l}\text { Polityka Transportowa Pań- } \\
\text { stwa na lata 2006-2025 }\end{array}$ \\
\hline 39. & $\begin{array}{l}\text { Wynik (nadwyżka/deficyt) sektora instytucji rządowych i samorza- } \\
\text { dowych w relacji do PKB (w \%) }\end{array}$ & UP \\
\hline 40. & $\begin{array}{l}\text { Produkt krajowy brutto na } 1 \text { mieszkańca według PPP }(\text { UE28=100) } \\
(\mathrm{w} \%)\end{array}$ & KSRR, SRK \\
\hline \multirow[t]{2}{*}{41.} & Stopa oszczędności krajowych brutto w relacji do PKB (w \%) & DSRK \\
\hline & \multicolumn{2}{|l|}{ Dziedzina: Zatrudnienie } \\
\hline $\begin{array}{l}42 . \\
43 . \\
44 . \\
45 .\end{array}$ & $\begin{array}{l}\text { Wskaźnik zatrudnienia osób w wieku 20-64 lata (w \%) } \\
\text { Czas trwania życia zawodowego (w latach) } \\
\text { Wskaźnik bierności ekonomiczno-społecznej młodzieży (w \%) } \\
\text { Współczynnik aktywności zawodowej (w \%) }\end{array}$ & $\begin{array}{c}\text { DSRK, SRKL, SRK, UP } \\
\text { SRKL } \\
\text { DSRK, SRKL, SRK } \\
\text { SRKL, KSRR, } \\
\text { SZRWRiR } \\
\end{array}$ \\
\hline 45. & \multicolumn{2}{|l|}{ Dziedzina: Innowacyjność } \\
\hline $\begin{array}{l}47 . \\
48 . \\
49 .\end{array}$ & $\begin{array}{l}\text { Udział przychodów netto ze sprzedaży produktów innowacyjnych } \\
\text { w przychodach netto ze sprzedaży (w \%) } \\
\text { Zasoby ludzkie dla nauki i techniki (w \%) } \\
\text { Wydajność pracy (rok poprzedni=100), (w \%) } \\
\text { Nakłady na działalność badawczo-rozwojową w relacji do PKB } \\
\text { (w \%) } \\
\text { Wskaźnik ekoinnowacyjności (UE=100) } \\
\text { Liczba wynalazków zgłoszonych przez rezydentów do Europej- } \\
\text { skiego Urzędu Patentowego na } 1 \text { mln mieszkańców }\end{array}$ & $\begin{array}{l}\text { SIEG } \\
\text { SIEG } \\
\text { SRK } \\
\text { DSRK, KSRR, } \\
\text { SIEG, UP } \\
\text { SIEG } \\
\text { DSRK }\end{array}$ \\
\hline 51. & \multicolumn{2}{|l|}{ Dziedzina: Transport } \\
\hline 52. & $\begin{array}{l}\text { Przewozy intermodalne ładunków transportem kolejowym nor- } \\
\text { malnotorowym }(\mathrm{w} \%)\end{array}$ & $\begin{array}{l}\text { Polityka Transportowa } \\
\text { Państwa na lata 2006- } \\
\text {-2025, SRT, SRK }\end{array}$ \\
\hline 53. & $\begin{array}{l}\text { Udział transportu kolejowego i wodnego śródlądowego w trans- } \\
\text { porcie ogółem (w \%) }\end{array}$ & $\begin{array}{l}\text { SRT, DSRK, Polityka } \\
\text { Transportowa Państwa } \\
\text { na lata 2006-2025, SRK }\end{array}$ \\
\hline 54. & $\begin{array}{l}\text { Udział długości linii kolejowych dostosowanych do prędkości } 160 \mathrm{~km} / \mathrm{h} \\
\text { i więcej w długości linii kolejowych eksploatowanych (w \%) }\end{array}$ & $\begin{array}{l}\text { SRT, DSRK, Polityka } \\
\text { Transportowa Państwa na } \\
\text { lata 2006-2025, SRK }\end{array}$ \\
\hline \multirow[t]{2}{*}{55.} & $\begin{array}{l}\text { Liczba przewozów pasażerskich w przeliczeniu na } 1 \text { mieszkańca } \\
\text { obszarów miejskich }\end{array}$ & KSRR, SRT \\
\hline & \multicolumn{2}{|l|}{ Dziedzina: Wzorce produkcji } \\
\hline 56. & Wydajność zasobów ( & SIEG \\
\hline 57. & $\begin{array}{l}\text { Udział powierzchni użytków rolnych gospodarstw ekologicznych w po- } \\
\text { wierzchni użytków rolnych ogółem (w \%) }\end{array}$ & $D S R K, S Z R W R i R$ \\
\hline 58. & $\begin{array}{l}\text { Organizacje ze Środowiskowym Systemem Ekozarządzania i Audytu } \\
\text { EMAS (w szt.) }\end{array}$ & $B E i S ́$ \\
\hline 59. & Odsetek zielonych zamówień publicznych (w \%) & BEiŚ, SIEG, SRK \\
\hline 60. & $\begin{array}{l}\text { Udział próbek artykułów rolno-spożywczych o niewłaściwej jakości } \\
\text { handlowej (w \%) }\end{array}$ & $S Z R W R i R, S R K$ \\
\hline
\end{tabular}




\section{ŁAD ŚRODOWISKOWY}

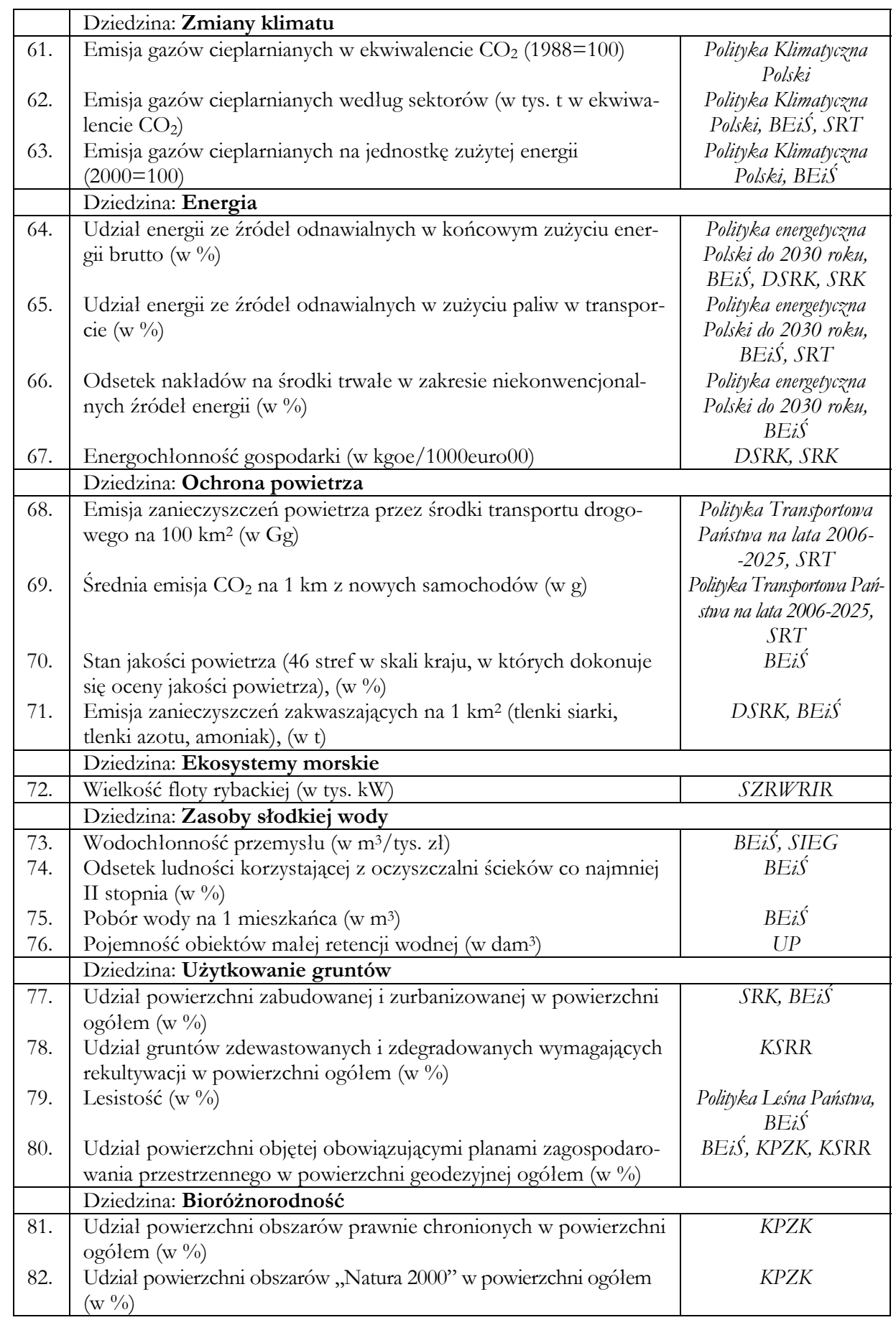




\begin{tabular}{|c|c|c|}
\hline 83. & $\begin{array}{l}\text { Uszkodzenia drzewostanów przez defoliację (w \%) } \\
\text { Wskaźnik liczebności ptaków pospolitych krajobrazu rolniczego } \\
\text { FBI }(2000=100)\end{array}$ & $\begin{array}{l}\text { Polityka Leśna Państwa, } \\
\text { BEiŚ } \\
\text { BEiŚ, DSRK, } \\
\text { SZRWRIR, SRK }\end{array}$ \\
\hline & \multicolumn{2}{|l|}{ Dziedzina: Gospodarka odpadami } \\
\hline 85. & Odpady niemineralne wytworzone na 1 mieszkańca (w kg) & $B E i S^{\prime}$ \\
\hline 86. & Odpady komunalne wytworzone na 1 mieszkańca (w kg) & SRK, BEiŚ \\
\hline 87. & $\begin{array}{l}\text { Odpady komunalne unieszkodliwiane poprzez składowanie na } 1 \text { miesz- } \\
\text { kańca (w kg) }\end{array}$ & DSRK, SRK, BEiŚ \\
\hline 88. & $\begin{array}{l}\text { Odpady komunalne zebrane selektywnie w relacji do ogółu odpadów } \\
\text { komunalnych (w \%) }\end{array}$ & KSRR, UP \\
\hline 89. & Recykling odpadów opakowaniowych (w \%) & KSRR \\
\hline
\end{tabular}

\section{ŁAD INSTYTUCJONALNO-POLITYCZNY}

\begin{tabular}{|c|c|c|}
\hline & \multicolumn{2}{|l|}{ Dziedzina: Finansowanie zrównoważonego rozwoju } \\
\hline 90. & Oficjalna Pomoc Rozwojowa (ODA) dla krajów rozwijajacych się (w \%) & - \\
\hline \multirow[t]{2}{*}{91.} & Polskie inwestycje bezpośrednie w krajach rozwijajacych się (w mln zł) & - \\
\hline & \multicolumn{2}{|l|}{ Dziedzina: Globalizacja handlu } \\
\hline \multirow[t]{2}{*}{92.} & Import z krajów rozwijających się według grup dochodowych (w mld euro) & - \\
\hline & \multicolumn{2}{|l|}{ Dziedzina: Polityka spójności i efektywności } \\
\hline \multirow{3}{*}{94.} & Poziom zaufania wobec instytucji publicznych $\left(\mathrm{w}^{0}\right.$ & SRKS, SSP, SRK \\
\hline & Wskaźnik postrzeganej korupcji (w punktach) & SSP \\
\hline & \multicolumn{2}{|c|}{$\begin{array}{l}\text { Dziedzina: Społeczeństwo obywatelskie - Otwartość i uczestnictwo oraz aktywność } \\
\text { obywatelska }\end{array}$} \\
\hline 95. & Frekwencja w wyborach parlamentarnych oraz samorządowych (w \%) & SRKS, KSRR \\
\hline 96. & $\begin{array}{l}\text { Odsetek gospodarstw domowych posiadających szerokopasmowy } \\
\text { dostęp do Internetu w domu (w \%) }\end{array}$ & SRK \\
\hline 97. & $\begin{array}{l}\text { Odsetek osób korzystających z Internetu w kontaktach z administra- } \\
\text { cją publiczną ( } \mathrm{w} \%)\end{array}$ & SSP, SRK, UP \\
\hline 98. & Wskaźnik zaufania (w punktach) & $D S R K, S R K S, S R K$ \\
\hline \multirow[t]{2}{*}{99.} & Odsetek osób angażujących się w wolontariat (w \%) & $S R K S$ \\
\hline & \multicolumn{2}{|l|}{ Dziedzina: Równoprawność w zarządzaniu } \\
\hline 100. & $\begin{array}{l}\text { Udział kobiet na stanowiskach kierowniczych w ogólnej liczbie } \\
\text { pracujących na stanowiskach kierowniczych (w \%) }\end{array}$ & $U P$ \\
\hline 101. & Udział kobiet w życiu publicznym (w \%) & $\begin{array}{l}\text { Krajony Program Driatań } \\
\text { na Rzecz Równego Trak- } \\
\text { towania na lata 2013-2016 }\end{array}$ \\
\hline
\end{tabular}

Źródło: opracowanie własne.

\section{Baza Wskaźników Zrównoważonego Rozwoju jako narzędzie służące do udostępniania i prezentacji wskaźników}

Oprócz prac metodologicznych i analitycznych dotyczących zrównoważonego rozwoju, w obszarze zainteresowania statystyki publicznej znajduje się również promocja tej idei rozwoju w drodze udostępniania i rozpowszechniania informacji z wcześniej wspomnianego zakresu. Realizacji tego celu służyć będzie Baza Wskaźników Zrównoważonego Rozwoju.

Prace związane z budową bazy są prowadzone w Urzędzie Statystycznym w Katowicach we współpracy z Urzędem Statystycznym we Wrocławiu. 
Zgodnie z przyjętym założeniem, wskaźniki w bazie są prezentowane w trzech modułach: krajowym (kraj, kraje członkowskie Unii Europejskiej), regionalnym (NTS1, NTS2) oraz lokalnym (NTS4) i pogrupowane według dziedzin w ramach czterech ładów. Baza Wskaźników Zrównoważonego Rozwoju zawiera także zestaw metadanych, w tym tzw. metryki wskaźników obejmujące m.in.: definicję, wyjaśnienia metodologiczne, znaczenie dla zrównoważonego rozwoju, pożądany kierunek zmian w powiązaniu z zasadami zrównoważonego rozwoju, monitorowane cele oraz obszary tematyczne odpowiadające tematom monitorującym zrównoważony rozwój w Unii Europejskiej.

TABELA 4.

Metryka wskaźnika - opis metodologiczny wskaźnika

\begin{tabular}{|c|c|}
\hline Nazwa wskaźnika & Opis wskaźnika \\
\hline Ład & $\begin{array}{l}\text { Społeczny, gospodarczy, środowiskowy, instytucjonal- } \\
\text { no-polityczny }\end{array}$ \\
\hline Obszar tematyczny & $\begin{array}{l}\text { Odniesienie do tematów przyjętych w Strategii Zrów- } \\
\text { noważonego Rozwoju Unii Europejskiej }\end{array}$ \\
\hline Dziedzina & $\begin{array}{l}\text { Wyodrębnione w ramach ładów tematy wymagające mo- } \\
\text { nitorowania }\end{array}$ \\
\hline Definicja & Informacje o sposobie obliczania wskaźnika \\
\hline Dostępne wymiary & $\begin{array}{l}\text { Przekrój, w jakim wskaźnik jest prezentowany w bazie, } \\
\text { np.: miasto/wieś, płeć }\end{array}$ \\
\hline Jednostka miary & Jednostki stosowane do pomiaru wielkości danego zjawiska \\
\hline Wyjaśnienia metodologiczne & $\begin{array}{l}\text { Dodatkowe informacje na temat danych wykorzystywa- } \\
\text { nych do obliczenia wskaźnika }\end{array}$ \\
\hline $\begin{array}{l}\text { Dokumenty strategiczne; monitorowane } \\
\text { cele }\end{array}$ & $\begin{array}{l}\text { Cel, priorytet lub działanie związane ze zrównoważo- } \\
\text { nym rozwojem, którego realizacja ma być monitorowana } \\
\text { za pomoca danego wskaźnika. Dotyczy tylko wskaźni- } \\
\text { ków modułu krajowego }\end{array}$ \\
\hline $\begin{array}{l}\text { Znaczenie dla zrównoważonego roz- } \\
\text { woju }\end{array}$ & $\begin{array}{l}\text { Zwiazek merytoryczny wskaźnika z opisywaną dziedzina } \\
\text { zrównoważonego rozwoju }\end{array}$ \\
\hline $\begin{array}{l}\text { Odniesienie do zasad zrównoważonego } \\
\text { rozwoju zawartych w Deklaracji z Rio, } \\
\text { Konferencja Narodów Zjednoczonych } \\
\text { „Środowisko i rozwój” }\end{array}$ & $\begin{array}{l}\text { Powiązanie zjawiska monitorowanego przez dany wskaźnik } \\
\text { z } 27 \text { zasadami zrównoważonego rozwoju zawartymi } \\
\text { w Deklaracï w spranie środoniska i rozpoju, przyjętej na Kon- } \\
\text { ferencji Narodów Zjednoczonych „Srodowisko i Roz- } \\
\text { wój” w Rio de Janeiro w czerwcu } 1992 \text { roku }\end{array}$ \\
\hline Pożądany kierunek zmian & $\begin{array}{l}\text { Ocena wpływu zmian wartości wskaźnika na mierzone } \\
\text { zjawisko }\end{array}$ \\
\hline Dostępność danych (w latach) & Lata, w których wskaźnik jest dostępny w bazie \\
\hline Dostępność na poziomie terytorialnym & $\begin{array}{l}\text { Dostępność wskaźnika w module (krajowym, regio- } \\
\text { nalnym, lokalnym) }\end{array}$ \\
\hline $\begin{array}{l}\text { Dostępność danych dla Unii Europej- } \\
\text { skiej }\end{array}$ & $\begin{array}{l}\text { Dostępność wskaźnika dla Unii Europejskiej oraz kra- } \\
\text { jów członkowskich w module krajowym }\end{array}$ \\
\hline Źródło danych & $\begin{array}{l}\text { Symbol i nazwa badania według Programu Badań Staty- } \\
\text { stycznych Statystyki Publicznej lub jeśli dane pochodzą } \\
\text { spoza programu badań, nazwa instytucji będącej źró- } \\
\text { dłem danych }\end{array}$ \\
\hline Data aktualizacji danych & Data wprowadzenia danych do bazy lub ich uaktualnienia \\
\hline Uwagi & Dodatkowe informacje dotyczące wskaźnika \\
\hline
\end{tabular}

Źródło: opracowanie własne. 
Ponadto, w zasobach systemu znajdują się m.in.: słownik pojęć, linki do krajowych i międzynarodowych aktów prawnych oraz dokumentów strategicznych związanych ze ZR, a także do instytucji zajmujących się wskaźnikami z tej dziedziny.

\section{RYSUNEK 2 .}

\section{Główna strona aplikacji Wskaźniki Zrównoważonego Rozwoju}

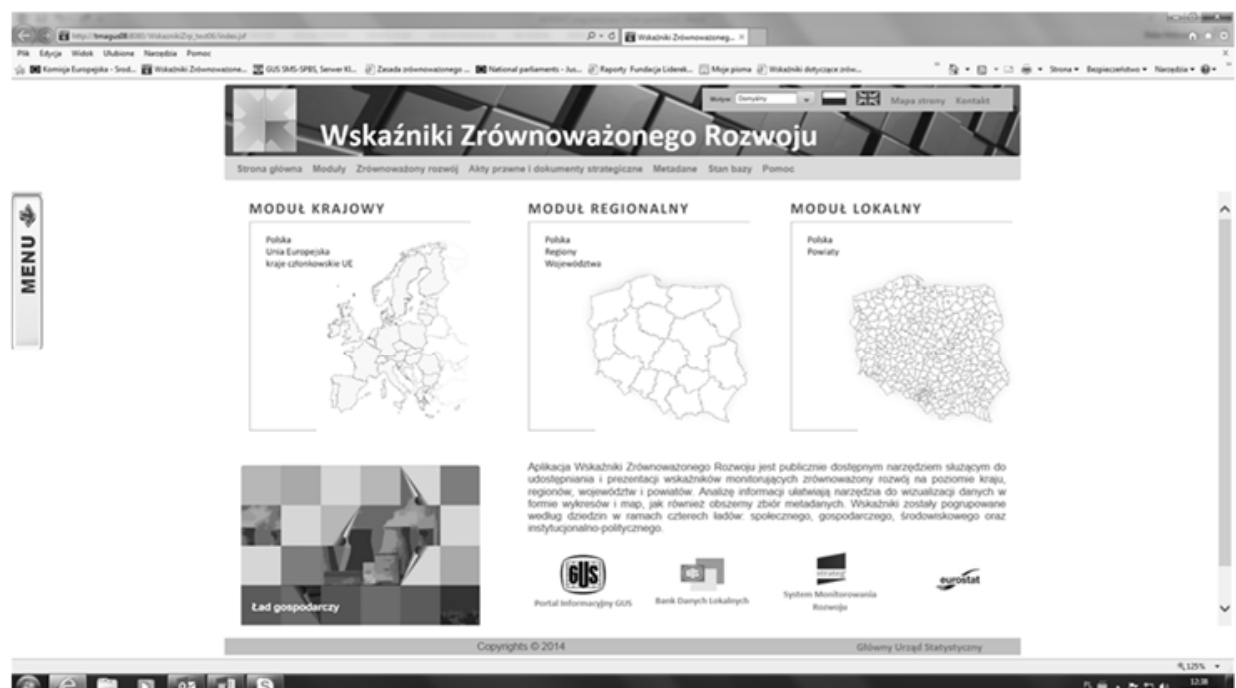

Źródło: [http://wskaznikizrp.stat.gov.pl/].

Prezentacja wskaźników w Bazie WZR ma charakter hierarchiczny, co przedstawia poniższy schemat struktury modułu.

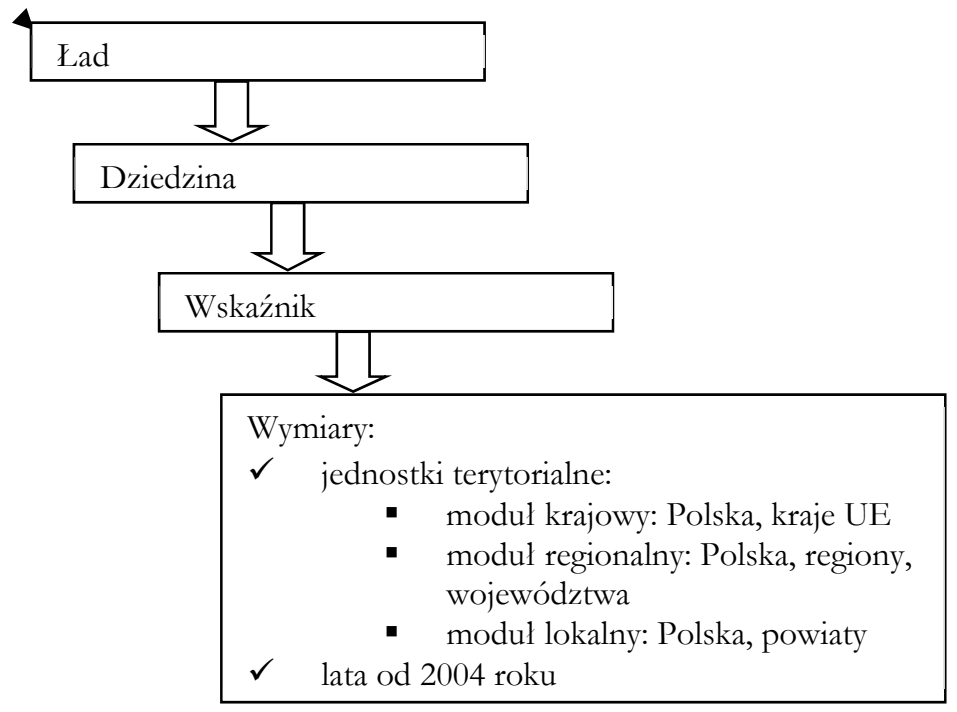


Po wyborze wskaźnika, w zależności od wybranego modułu, są dostępne poniższe zakładki.

\section{Moduł krajowy}

\begin{tabular}{|l||l|l||l||}
\hline \hline Polska & $\begin{array}{l}\text { Porównanie wskaźników } \\
\text { modułu krajowego }\end{array}$ & $\begin{array}{l}\text { Porównanie międzyna- } \\
\text { rodowe }\end{array}$ \\
\hline
\end{tabular}

Tablice

Prezentacja w tablicy danych dla Polski oraz wybranego z menu wskaźnika modułu krajowego.

\begin{tabular}{||l||l||}
\hline $\begin{array}{l}\text { Prezentacja w tablicach } \\
\text { danych dla więcej niż } \\
\text { jednego wskaźnika mo- } \\
\text { dułu krajowego oraz } \\
\text { jednego wybranego ob- } \\
\text { szaru terytorialnego } \\
\text { (Polska, kraje UE). }\end{array}$ & $\begin{array}{l}\text { Prezentacja w tablicy danych dla wskaźnika } \\
\text { modułu krajowego i wybranych krajów UE } \\
\text { oraz lat. }\end{array}$ \\
\hline
\end{tabular}

Wykresy liniowe (lub punktowe) oraz kolumnowe

Predefiniowany wykres z danymi dla Polski.

Wykresy z danymi dla
wybranych wskaźni-
ków oraz wybranego
wcześniej w tablicy
kraju Unii Europej-
skiej.

Wykres z danymi dla wybranego wskaźnika oraz poszczególnych krajów członkowskich UE i wybranych lat.
Mapy

Prezentacja danych dla wybranego wskaźnika na mapie dla krajów UE.

\section{Moduł regionalny}

\begin{tabular}{||l||l||l||}
\hline \hline Polska & $\begin{array}{l}\text { Porównanie wskaźni- } \\
\text { ków modułu } \\
\text { regionalnego }\end{array}$ & $\begin{array}{l}\text { Porównanie } \\
\text { regionalne }\end{array}$ \\
\begin{tabular}{|l||l||l||}
\hline Prezentacja w tablicy \\
danych dla Polski oraz \\
wybranego z menu \\
wskaźnika modułu \\
regionalnego.
\end{tabular} & $\begin{array}{l}\text { Prezentacja w tablicach } \\
\text { danych dla więcej niż } \\
\text { jednego wskaźnika mo- } \\
\text { dułu regionalnego i jed- } \\
\text { nego wybranego obsza- } \\
\text { ru terytorialnego (Pol- } \\
\text { ska, region, wojewódz- } \\
\text { two). }\end{array}$ & $\begin{array}{l}\text { Prezentacja w tablicy danych dla wskaźnika modułu } \\
\text { regionalnego dla wybranych lat, regionów i/lub } \\
\text { województw oraz lat. }\end{array}$ \\
\hline$\square$
\end{tabular}




\begin{tabular}{|l||l||l||}
\hline \hline Predefiniowany wy- & Wykresy z danymi dla & Wykres z danymi dla \\
kres z danymi dla Pol- & wybranych wskaźni- & wybranego wskaźnika \\
ski. & ków oraz wybranego & oraz wybranych wcze- \\
& wcześniej w tablicy re- & śniej w tablicy regionów \\
& gionu lub województwa. & lub województw i lat. \\
\hline
\end{tabular}

Prezentacja danych dla wybranego wskaźnika na mapie dla:

- regionów, - województw.

\section{Moduł lokalny}

\begin{tabular}{|l||l||l||}
\hline \hline Polska & $\begin{array}{l}\text { Porównanie wskaźni- } \\
\text { ków modułu lokalnego }\end{array}$ & Porównanie lokalne \\
\hline Tablice & Metryka \\
\hline
\end{tabular}

Prezentacja w tablicy danych dla Polski oraz wybranego z menu wskaźnika modułu lokalnego.

\begin{tabular}{||l||l||l||}
\hline \hline $\begin{array}{l}\text { Prezentacja w tablicy } \\
\text { danych dla Polski oraz } \\
\text { wybranego z menu } \\
\text { wskaźnika modułu } \\
\text { lokalnego. }\end{array}$ & $\begin{array}{l}\text { Prezentacja w tablicach } \\
\text { danych dla więcej niz } \\
\text { jednego wskaźnika mo- } \\
\text { dułu lokalnego oraz jed- } \\
\text { nego wybranego obsza- } \\
\text { ru terytorialnego (Pol- } \\
\text { ska, powiat). }\end{array}$ & $\begin{array}{l}\text { Prezentacja danych w tablicy dla wskaźnika mo- } \\
\text { dułu lokalnego, wybranych powiatów/grup po- } \\
\text { wiatów oraz lat. }\end{array}$ \\
\hline Wykresy liniowe (lub punktowe) oraz kolumnowe
\end{tabular}

Prezentacja w tablicach $\mid$ Prezentacja danych w tablicy dla wskaźnika modanych dla więcej niż dułu lokalnego, wybranych powiatów/grup pojednego wskaźnika modułu lokalnego oraz jednego wybranego obszaru terytorialnego (Polka, powiat).

\begin{tabular}{||c||}
\hline Możliwość genero- \\
wania następujących \\
map: \\
$\checkmark$ \\
Polska-powiaty \\
- dla powiatów \\
w kraju; \\
$\checkmark$ Regiony-powia- \\
ty - dla powia- \\
tów w ramach \\
wybranego re- \\
gionu; \\
$\checkmark$ Województwa \\
-powiaty - dla \\
powiatów w ra- \\
mach wybrane- \\
go wojewódz- \\
twa. \\
\hline
\end{tabular}

Każdy z modułów daje użytkownikowi możliwość prezentacji danych w formie tabelarycznej i graficznej, w postaci wykresów oraz map. Możliwe jest uzyskanie danych dla danego wskaźnika w postaci pliku pdf i xls. 
Aplikacja Wskaźniki Zrównoważonego Rozwoju została udostępniona na Portalu Informacyjnym GUS w zakładkach: Banki i basy danych oraz Zrównoważony rozwój.

\section{Podsumowanie}

Zadaniem polskiej statystyki publicznej w kolejnych latach będzie kontynuacja prac nad zestawem wskaźników zrównoważonego rozwoju w celu: ich aktualizacji, uwzględnienia nowych celów strategicznych oraz poszukiwania mierników najpełniej obrazujących koncepcję zrównoważonego rozwoju w warunkach krajowych. Lista wskaźników zrównoważonego rozwoju kraju będzie podlegać modyfikacji przez dobór nowych mierników oraz rezygnację ze wskaźników, które straciły na swojej aktualności. W dalszych pracach analitycznych będą także brane pod uwagę zapisy dokumentów o charakterze międzynarodowym, w tym m.in. nowego, globalnego programu na rzecz zrównoważonego rozwoju, tj. Agendy po 2015 roku, w której sformułowano 17 celów głównych oraz 169 podcelów. Jednocześnie jest planowana dalsza rozbudowa i aktualizacja Bazy Wskaźników Zrównoważonego Rozwoju, w tym jest rozważana możliwość wprowadzenia modułu wskaźników monitorujących realizacje celów sformułowanych w Agendizie po 2015 roku.

\section{Wkład autorów w powstanie artykułu}

Aleksandra Balas - opracowanie zestawu wskaźników zrównoważonego rozwoju oraz prace merytoryczne dotyczące Aplikacji Wskaźniki Zrównoważonego Rozwoju - 50\%

Anna Molenda - opracowanie zestawu wskaźników zrównoważonego rozwoju oraz prace merytoryczne dotyczące Aplikacji Wskaźniki Zrównoważonego Rozwoju - 50\%

\section{Literatura}

Agenda 21, 1992, Konferencja Narodów Zjednoczonych, Rio de Janeiro.

Borys T., 2010, Wskaźniki Zrównoważonego Rozwoju - efektywna forma konkretyzacji nowego paradygmatu rozzoju, C₹: 1. Co chcemy miersyc??, „Zielona Planeta”, nr 3(90).

Borys T., Fiedor B., 2008, Operacjonalizacja i pomiar kategorii zrónnoważonego rozwoju pr:yycrynek do dyskusji, [w:] Racbunki narodowe. Wybrane problemy i prsylkłady zastosowań, M. Plich (red.), Główny Urząd Statystyczny, Uniwersytet Lódzki, Warszawa.

Dtugookresowa Strategia Rozwoju Kraju. Polska 2030. Trzecia fala nowoczesności, 2013, Ministerstwo Administracji i Cyfryzacji, Warszawa.

Europa 2020. Strategia na rzecz inteligentnego $i$ zrównoważonego rozwoju sprayjajacego wtaczeniu spotecznemu, Bruksela, 3.3.2010, KOM(2010) 2020, wersja ostateczna.

II Polityka Ekologiczna państwa (dokument zperspektywa do 2025 roku), dokument przyjęty przez Radę Ministrów w czerwcu 2000 roku i Sejm RP w sierpniu 2001 roku. 
Koncepcja Przestrzennego Zagospodarowania Kraju 2030, MP 2012, poz. 252.

Konstytucja Rzeczypospolitej Polskiej z dnia 2 kinietnia 1997 roku, Dz.U. 1997, Nr 78, poz. 483 z późn. zm.

Krajowa Strategia Rozwoju Regionalnego 2010-2020: Regiony, Miasta, Obszary wiejskie, 2010, Ministerstwo Rozwoju Regionalnego, Warszawa.

Narodowe Strategiczne Ramy Odniesienia 2007-2013 wspierajace warost gospodarczy $i$ zatrudnienie. Narodowa Strategia Spójności, 2007, Ministerstwo Rozwoju Regionalnego, Warszawa.

Odnowiona Strategia Trwałego Rozwoju Unii Europejskiej, 2006, Rada UE, Bruksela.

Our Common Future, 1987, United Nations, New York.

Polityka ekologiczna państwa w latach 2009-2012 zperspektywa do roku 2016, 2008, Ministerstwo Ochrony Środowiska, Warszawa.

Polityka Energetyczna Polski do 2030 roku, 2009, Ministerstwo Gospodarki, Warszawa.

Polityka Klimatyczna Polski - Strategie Redukcji Emisji Gazów Cieplarnianych w Polsce do roku 2020, 2003, Ministerstwo Środowiska, Warszawa.

Polityka Leśna Państwa, 1997, Ministerstwo Ochrony Środowiska, Zasobów Naturalnych i Leśnictwa, Warszawa.

Polityka Transportowa Państwa na lata 2006-2025, 2005, Ministerstwo Infrastruktury, Warszawa.

Programowanie perspektywy finansowej 2014-2020 - Umowa Partnerstwa, 2015, Ministerstwo Rozwoju, Warszawa.

Prayszłłośc jakiej chcemy, 2012, dokument końcowy Konferencji Narodów Zjednoczonych w sprawie Zrównoważonego Rozwoju RIO +20 .

Strategia Beapiecz̧eństwo Energetyczne i Środowisko - perspektywa do 2020 roku, 2014, Ministerstwo Gospodarki, Ministerstwo Środowiska, Warszawa.

Strategia Innowacyjności i Efektywności Gospodarki Dynamiczna Polska 2020, 2013, Ministerstwo Gospodarki, Warszawa.

Strategia Rozwoju Kapitału Ludzkiego 2020, 2013, Ministerstwo Pracy i Polityki Społecznej, Warszawa.

Strategia Rozwoju Kapitału Ludzkiego 2020, 2014, Ministerstwo Pracy i Polityki Społecznej, Warszawa.

Strategia Rozwoju Kapitalu Spotecznego 2020, MP 2013, poz. 378.

Strategia Rozwoju Kraju 2020, 2012, Ministerstwo Rozwoju Regionalnego, Warszawa.

Strategia Rozwoju Systemu Bezpieczeństwa Narodowego Rzeczypospolitej Polskiej 2022, MP 2013, poz. 377.

Strategia Rozwoju Transportu do 2020 r. (z.perspektywa do 2030 r.), 2013, Ministerstwo Transportu, Budownictwa i Gospodarki Morskiej, Warszawa.

Strategia Sprawne Państwo 2020, MP 2013, poz. 136.

Strategia Zrównoważonego Rozwoju Wsi, Rolnictwa i Rybactwa na lata 2012-2020, 2012, Ministerstwo Rolnictwa i Rozwoju Wsi.

Sustainable Development in the European Union - 2013 monitoring report of the EU Sustainable Development Strategy, 2013, Eurostat, Publications Office of the European Union, Luxembourg. 
Ustawa z. dnia 27 kwietnia 2001 r. Prawo Ochrony Środowiska, Dz.U. 2001, Nr 62, poz. 627 z późn. zm.

Wskaźniki Zrónnoważonego Rožwoju, 2005, T. Borys (red.) Wydawnictwo Ekonomia i Środowisko, Warszawa-Białystok.

Wskaźniki arónnoważonego rožwoju Polski 2011, 2011, Główny Urząd Statystyczny, Urząd Statystyczny Katowice, Katowice.

Wskaźniki Zrównoważonego Roz̧woju Polski, Urząd Statystyczny w Katowicach, http://wskaznikizrp.stat.gov.pl/. 